\title{
The Genitive Case in the New Testament ${ }^{\dagger}$
}

\author{
J. Harold Greenlee
}

In a majority of cases the English preposition "of" furnishes a serviceable translation for the Greek genitive case. This is a convenience for one who is translating from Greek into English; but it is a serious fallacy for the translator to assume that this translation necessarily makes clear, either to his readers or to himself, the meaning of the passage. On the contrary, both the English preposition and the Greek case have a large number of meanings; fortunately (or unfortunately) the range of meaning of "of" corresponds largely to the range of meaning of the Greek genitive case. Webster's Collegiate Dictionary lists fourteen meanings for "of"; grammarians would give varying numbers of uses of the genitive case (genitive and ablative cases, according to some scholars), but the number would be approximately equal to the number of uses of the English preposition. We speak of "the kingdom of God," "the love of God" (which has two possible meanings), "the city of Jerusalem," to name but a few examples of the Greek genitive case. What, then, are the possible meanings conveyed by the English "of" as well as the instances when it is otherwise translated?

\section{Possessive Genitive}

The most commonly recognized use of the genitive case is to express possession. The possessive genitive in the New Testament, in such expressions as "his disciples," "my son," "the house of Simon," is so obvious and common as to require no further comment.

Subjective and Objective Genitiyn ofiog genitive case. Paul speaks of being "in

Somewhat different is the twofold use on perits of rivers, in perils of robbers" (II of the genitive case, which may be desig- Coral1:26), referring to rivers and robnated as the "subjective" and "objective" bers sources of his dangers; that is, in genitives. With a subjective genitive, an perils from rivers and from robbers. John action or idea is set forth as proceeding 6.45," "And they shall all be taught of from the noun in the genitive case; with an $\uparrow$ Reprinted by permission from The Bible objective genitive, the idea $\mathrm{OB}_{\mathrm{E}}$ action thought of as being directed toward the noun in the genitive case. John 2:6 speaks of six stone water jars sitting "according to the cleansing of the Jews." The italicized phrase may be interpreted as a subjective genitive referring to a cleansing which the Jews customarily performed, i.e., action proceeding from the Jews. On the other hand, 2 Corinthians 10:5 refers to leading every thought captive to "the obedience of Christ," which is apparently an objective genitive, the obedience to be derected to Christ. A phrase which may variously be interpreted as either a subjective or objective genitive is "the love of God." Scholars differ in their interpretation of specific passages, but the following examples may cautiously be suggested: 2 Cor. $13: 14$ reads, "The grace of the Lord Jesus Christ, and the love of God, and the fellowship of the Holy Spirit, be with you all." These blessings seem to be spoken of as being bestowed by the Persons of the Trinity, so that here "the love of God" is the love which comes from God to man-a subjective genitive. I John 5:3 reads, "For this is the love of God, that we keep his commandments...." To keep God's commandments is the test of our love for God, not of God's love for us; hence this is the objective genitive. That this is the proper interpretation seems to be borne out also by the fact that the sentence immediately preceding speaks of our loving God and keeping His commandments.

\section{Genitive of Source}

A source or author may be expressed by . 
God," refers to God as the author of the teaching, the words "of God" being in the genitive case.

\section{Genitive of Material}

The material of which a thing is made may also be expressed by the genitive case. Examples of this usage are found in Mark $2: 21$, "No one sews a patch of unshrunk cloth upon an old garment...." and John 7:38, "rivers of living water." Somewhat related is the partitive genitive, the genitive case naming the whole from which only a part is to be considered. Similar to the former example is Luke 24: 42 , "and they gave him a piece of broiled fish." More common, however, are such instances as "some of the scribes" (Matt. 9:3), and "the half of my goods" (Luke 19:8). Also related to the genitive of material is the genitive case used to express apposition, where the noun in the genitive further identifies another noun or tells of what it consists. Apposition, in Greek as in English, is usually expressed by placing the two nouns in the same case, as "James the son" or "Paul the servant"; but in some usages the noun in apposition is placed in the genitive case. Examples are John $2: 21$, "But he was speaking concerning the sanctuary of his body" (the sanctuary was his body), and the series of figures of speech in Eph. $6: 14-17$, ". . . the breastplate of righteous$n e s s, \ldots$ the shield of faith, ....the helmet of salvation,....", among others.

Comparative Genitive

Not all the uses of the Greek genitive case, however, are translated by the English prepositional phrase with "of." A comparison, for instance may be expressed in Greek by using the genitive case for the second member of the comparison. Perhaps one of the most notable examples of this construction in the New Testament is found in John $21: 15$, where Jesus says, "Simon, son of John, lovest thou me more than these?" - the italicized words being extocinto their exact equivalents in another pressed in Greek by the word "theses in langatage, nor is the interpretation of a pasthe genitive case, no word being necessary ansage the mere mechanical application of obin the Greek for the word "than." Thiere jective rules. It is therefore only by continuis, however, an alternate construction in dily seeking a more thorough understanding Greek to express a comparison, namely, to of the language, the style, the grammar of use the Greek word for "than" with both the New Testament that one can fit himself members of the comparisolf ${ }^{\circ}$ in copying of constructions from one language

the first member. The New Testament student may regret that the author did not use it in this passage. The difficulty is that "these" in the genitive plural has the same form for masculine, feminine, and neuter, and the question of Jesus could, grammatically, be either "Do you love me more than these other disciples love me?" "Do you love me more than you love these thingsyour boat and nets?" (or even: "Do you love me more than you love these other disciples?") If the other construction had been used in the Greek, the word "these" would have had a different form to express each of the three questions, and commentators would have been spared a great deal of time debating this phase of the interpretation of this passage.

Temporal Genitive

Time within which an event takes place is also expressed by the genitive case. In John $3: 2$, which tells us that Nicodemus came to Jesus "by night," the time is expressed by the single word "night" written in the genitive case.

Miscellaneous Uses of the Genitive

Price and penalty are written in the genitive case, as in Matt. 10:29, "Are not two sparrows sold for a farthing?" Fulness or lack is expressed by the genitive, as, John 2:7, "Fill the water jars zith z'ater." Verbs expressing a mental perception, e.g. hearing, tasting, touching, may take a genitive case, parallel to the English phrase "to taste of the food." Finally, the genitive case is often used to express a loose relationship which often cannot be specifically categorized. Examples are John 1:15, "he was first (in respect) of me"; Mark 1:4, "a baptism of repentance" (a baptism which had reference to repentance); and Rom. 7:2, "she is freed from the law of her husbland" (the law which defines that relationship).

Translation is by no means the mere

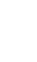

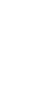

